\title{
EFFECT OF FIPRONIL ON OXYGEN CONSUMPTION AND AMMONIA EXCRETION OF MAHSEER (TOR KHUDREE) FRY
}

\author{
H. B. DHAMGAYE* ${ }^{* 1}$, S. P. JADHAO ${ }^{1}$, S. J. MESHRAM ${ }^{1}$, \\ B. R. CHAVAN ${ }^{1}$ AND R. K. SADAWARTE ${ }^{1}$
}

${ }^{1}$ College of Fisheries, Dr. B. S. Konkan Krishi Vidyapeeth, Dapoli, Shirgaon, Ratnagiri (MS) - 415612 , Maharashtra, India

\begin{abstract}
The purpose of this study was to determine the lethal toxicity and effect of fipronil on oxygen consumption rate, ammonia excretion rate and $\mathrm{O}: \mathrm{N}$ ratio of Mahseer fry. The bioassay test was performed by adopting static renewal method. Results showed that the median lethal concentration $\left(\mathrm{LC}_{50}\right)$ of fipronil for $96 \mathrm{hrs}$ was $64.6 \mu \mathrm{gL}^{-1}$ at $28 \pm 2^{\circ} \mathrm{C}$. One tenth $\left(6.46 \mu \mathrm{gL}^{-1}\right)$ and one fifth $\left(12.92 \mu \mathrm{gL}^{-1}\right)$ of $\mathrm{LC}_{50}$ values was selected for sublethal studies. The rate of oxygen consumption, ammonia excretion and $O: \mathrm{N}$ ratio was examined under two sublethal concentrations $\left(6.46 \mu \mathrm{gL}^{-1}\right.$ and $\left.12.92 \mu \mathrm{gL}^{-1}\right)$ of fipronil at 7 days intervals for 28 days. The results obtained in this study proposed that measurements of oxygen consumption rate, ammonia excretion and $\mathrm{O}: \mathrm{N}$ ratio can be useful indicators of stress .
\end{abstract}

Key words: Ammonia excretion, Fipronil, Oxygen consumption, O:N ratio, Tor khudree

Fipronil is a phenylpryazole insecticide that was registered for use in 1996. It is registered for use on commercial and residential turf. Fipronil covers four significant areas: plant insurance of harvests and ornamentals against herbivorous bugs and parasites, urban vermin control on track destructive living beings, for example, cockroaches, ants, termites, wasps, flies, and so on., veterinary applications against insects, ticks, and so forth on pets and cows, and bugs in cows pens (Chagnon et al., 2015). Fish are particularly sensitive to the environmental contamination of water. The contamination of surface water by insecticides is known to have dangerous effects on the growth, survival and reproduction of fishes. Pollutants such as insecticides may significantly damage certain physiological and biochemical processes that can cause serious impairment to health status of fishes.

The IUCN has listed T. khudree as an 'Endangered' species based on circumstantial evidence of the population decline (Devi and Boguskaya, 2007). In India Mahseer is cultured mostly and stocked in reservoirs from conservation point of view. However, the hatcheries are usually supplied fry size only for stocking in reservoir (Pinder and Raghavan, 2013). These reservoirs have many point and non-point sources of pollution, which adds many toxic materials including pesticides through runoff during rainy season. Therefore, this study was proposed to investigate lethal toxicity and effects of fipronil fry to know the physiological response of Mahseer fry.

\section{MATERIALS AND METHODS}

Test insecticide: The pesticide, fipronil 5-amino1-[2,6-dichloro-4-(trifluoromethyl) phenyl-4 (trifluoromethylsulfinyl) pyrazole-3-carbonitrile, was obtained from local market for assessing the toxicity study on physiological changes in Mahseer

\footnotetext{
"Corresponding Author
} 
fry. The stock solution was prepared having strength of $1000 \mathrm{ppm}$ by adding $20 \mathrm{~mL}$ of fipronil (5\% active component) in $1000 \mathrm{~mL}$ distilled water. Calculated amount of stock solution was added to water and mixed thoroughly to arrive at required levels of working concentrations/ dilutions.

Test animal: Deccan Mahseer, Tor khudree of fry size (length $2.5 \pm 0.171 \mathrm{~cm}$ and weight $0.5 \pm 0.051 \mathrm{~g}$ ) was obtained from Tata power hatchery, Lonavala Maharashtra. The fish was acclimatized in FRP tank for a period of one week. During acclimatization, fishes were fed twice a day with rice bran and groundnut oil cake (GOC). After acclimatization, healthy fishes were selected from the stock and transferred to the experimental tanks. Feeding was stopped one day before the commencement of experiment.

Lethal toxicity: Lethal toxicity study was carried out by following the standard guidelines of EPAR (1998) to determine the median lethal concentrations $\left(\mathrm{LC}_{50}\right)$ of fipronil on test fish for $96 \mathrm{~h}$ by Probit analysis method (Finney, 1971). The experiment was carried out in all glass tanks of $40 \mathrm{~L}$ capacity and tank filled with $30 \mathrm{~L}$ water. Initially, a range finding test was conducted to ascertain the range to be selected in the definitive test. During the trial, the animals were exposed to a range of concentration viz. 55, 60, 65, 70, 75 and $80 \mu \mathrm{gL}^{-1}$. Bioassay test was conducted in triplicate for each concentration of fipronil with 20 fry in each tank and also appropriate controls were maintained for a period of $96 \mathrm{~h}$ in the laboratory condition and percentage mortality was recorded at 24, 48, 72, and $96 \mathrm{~h}$ interval. The test animals were exposed to a fresh solution of the selected concentrations and at every $24 \mathrm{~h}$ by transferring them from one test chamber to another chamber with test solution of the same concentration. Percentage mortality was recorded at 24, 48, 72 and $96 \mathrm{~h}$ interval and dead fish were removed immediately. The median lethal concentration $\left(\mathrm{LC}_{50} 64.6 \mu \mathrm{gL}^{-1}\right)$ of fipronil at $96 \mathrm{~h}$ was determined by Probit analysis (Finney, 1971).
Exposure to sublethal doses of the insecticide: Fishes were exposed to the sublethal concentrations of $6.46 \mu \mathrm{gL}^{-1}$ and $12.92 \mu \mathrm{gL}^{-1}(1 /$ $10^{\text {th }}$ and $1 / 5^{\text {th }}$ of $96 \mathrm{~h} \mathrm{LC}_{50}$ value respectively) of fipronil for 28 days in test chambers. Parallel controls were maintained. Ten fishes were stocked in each test chamber (40 L capacity all glass aquarium tank) in $30 \mathrm{~L}$ test solution per concentration in triplicate. The Mahseer fry were fed (rice bran and GOC) @10\% of their body weight (Brahmane et al., 2014) in the morning (10.00 hrs) and evening (17.00 hrs). The test medium was renewed every $24 \mathrm{~h}$. Both control and exposed samples were drawn at intervals of 7, 14, 21 and 28 days for estimation of $\mathrm{O}_{2}$ consumption, $\mathrm{NH}_{3}-\mathrm{N}$ excretion and $\mathrm{O}: \mathrm{N}$ ratio.

The respiration chamber was fabricated locally in laboratory as described by (Job, 1957) with some modification. The thermocol cap was made to fit in the neck of $2 \mathrm{~L}$ conical flask. The paraffin wax was applied around the thermocol cap to prevent entry of atmospheric air. A small hole was made into thermocol cap and an aeration tube was inserted through hole for taking water sample at each interval from chamber and also for filling up chamber. One end of aeration tube was inside the chamber while the other end was closed during the experiment.

At the end of 7 days exposure, 5 fishes were transferred from test chamber i.e. glass tank (40 L capacity) to respiratory chamber of $2 \mathrm{~L}$ capacity with same concentration in accordance with the test chamber. The fish was allowed to stabilize for half an hour and then experiment was run for a period of $3 \mathrm{~h}$. Oxygen (Winkler's method, Golterman et al., 1969) and $\mathrm{NH}_{3}-\mathrm{N}$ (Nessler method, APHA, 2012) were measured (initially and after completion of $3 \mathrm{~h}$ duration). Control was also run simultaneously to obtain information on fish in normal state. After the experiment, the test fish was weighed and placed in their respective test chamber. The same process was repeated after 14, 21 and 28 days of sampling intervals. Initial and final samples were taken for estimation of $\mathrm{O}_{2}$ and 
$\mathrm{NH}_{3}-\mathrm{N}$ excretion rate as described by (Zhen et al., 2010). The O:N ratio was calculated as the ratio of atoms of oxygen consumed to atoms of nitrogen excreted in the time interval (Widdows, 1985).

Statistical analysis: The average $\mathrm{O}_{2}$ consumption rate, ammonia excretion rate and $\mathrm{O}: \mathrm{N}$ ratio of the fish were analysed using one way ANOVA followed by Duncan's Multiple Range Test $(\mathrm{p}<0.05)$.

\section{RESULTS}

Lethal toxicity: The $96 \mathrm{~h} \mathrm{LC}_{50}$ of fipronil against Tor khudree was calculated to be 64.6 $\mu \mathrm{g}^{-1}$ depicted in Fig. 1.

Oxygen consumption: Fipronil affected $\mathrm{O}_{2}$ consumption rate of fish at sublethal concentration is in between $6.46 \mu \mathrm{gL}^{-1}$ and $12.92{\mu \mathrm{gL}^{-1}}^{-}$(Table 1 and Fig. 2). The result indicate that the $\mathrm{O}_{2}$ consumption rate reduced progressively by $21 \%$ and $39 \%$ on $7^{\text {th }}$ day and $65 \%$ and $82 \%$ on $28^{\text {th }}$ day at 6.46 and 12.92 $\mu \mathrm{gL}^{-1}$ concentrations, respectively as compared to control.

$\mathbf{N H}_{3}-\mathbf{N}$ excretion: The $\mathrm{NH}_{3}-\mathrm{N}$ excretion rate of Tor khudree under both the sublethal concentrations of fipronil is presented in Table 1 and Fig. 3. The rate of ammonia excretion was progressively increased by $6 \%, 15 \%, 28 \%$ and $42 \%$ on $7,14,21$ and 28 days respectively at 6.46 $\mu \mathrm{gL}^{-1}$ concentration of fipronil whereas in 12.92 $\mu \mathrm{gL}^{-1}$ concentration of fipronil, the rate of ammonia excretion percentage was progressively increased as $12 \%, 25 \%, 42 \%$ and $57 \%$ on $7,14,21$ and 28 days sampling interval. However the rate of increased in percentage is in $12.92 \mu \mathrm{gL}^{-1}$ higher as compared to $6.46 \mu \mathrm{gL}^{-1}$ at all sampling intervals.

O:N Ratio: The O:N ratio of Mahseer fry at two sub-lethal concentrations is presented in Table 1 and Fig. 4. Mahseer fry showed a gradual decrease of $17 \%$ to $40 \%$ and $31 \%$ to $59 \%$ on 7 and 28 days at $6.46 \mu \mathrm{gL}^{-1}$ and $12.92 \mu \mathrm{gL}^{-1}$ concentrations respectively, compared to the control.

Table 1. Changes in oxygen consumption rate, ammonia-N-excretion rate and oxygen nitrogen ratio in Tor khudree when exposed to sublethal concentration of fipronil

\begin{tabular}{|c|c|c|c|c|c|c|}
\hline Parameter & $\begin{array}{l}\text { Experimental } \\
\text { period } \\
\text { (Days) }\end{array}$ & Control & $\begin{array}{c}\text { Fipronil concn. } \\
6.46 \mu g L^{-1} \\
\left(1 / 10^{\text {th }} \mathbf{L C}_{50}\right) \\
\end{array}$ & $\begin{array}{c}\text { Change } \\
(\%)\end{array}$ & $\begin{array}{c}\text { Fipronil concn. } \\
12.92 \mu g L^{-1} \\
\left(1 / 5^{\text {th }} \mathbf{L C}_{50}\right)\end{array}$ & $\begin{array}{c}\text { Change } \\
(\%)\end{array}$ \\
\hline \multirow{4}{*}{$\begin{array}{c}\text { Oxygen } \\
\text { consumption } \\
\text { rate } \\
\left(\mathrm{mg} \mathrm{g}^{-1} \mathrm{~h}^{-1}\right)\end{array}$} & 7 & $0.23 \pm 0.003^{\mathrm{a}}$ & $0.18 \pm 0.005^{\mathrm{b}}$ & -21 & $0.14 \pm 0.005^{\mathrm{c}}$ & -39 \\
\hline & 14 & $0.22 \pm 0.003^{\mathrm{a}}$ & $0.15 \pm 0.005^{\mathrm{b}}$ & -31 & $0.10 \pm 0.005^{\mathrm{c}}$ & -54 \\
\hline & 21 & $0.23 \pm 0.005^{\mathrm{a}}$ & $0.12 \pm 0.005^{\mathrm{b}}$ & -47 & $0.07 \pm 0.003^{c}$ & -69 \\
\hline & 28 & $0.23 \pm 0.005^{\mathrm{a}}$ & $0.08 \pm 0.005^{\mathrm{b}}$ & -65 & $0.04 \pm 0.005^{\mathrm{c}}$ & -82 \\
\hline \multirow{4}{*}{$\begin{array}{l}\text { Ammonia- } \mathrm{N} \\
\text { excretion } \\
\text { rate } \\
\left(\mathrm{mg} \mathrm{g}^{-1} \mathrm{~h}^{-1}\right)\end{array}$} & 7 & $0.0081 \pm 0.00006^{\mathrm{a}}$ & $0.0076 \pm 0.00008^{b}$ & -6 & $0.0071 \pm 0.00005^{c}$ & -12 \\
\hline & 14 & $0.0082 \pm 0.0000^{\mathrm{a}}$ & $0.0069 \pm 0.00008^{b}$ & -15 & $0.0061 \pm 0.00003^{c}$ & -25 \\
\hline & 21 & $0.0082 \pm 0.00008^{\mathrm{a}}$ & $0.0059 \pm 0.00008^{\mathrm{b}}$ & -28 & $0.0047 \pm 0.0001^{\mathrm{c}}$ & -42 \\
\hline & 28 & $0.0083 \pm 0.00008^{\mathrm{a}}$ & $0.0048 \pm 0.0001^{\mathrm{b}}$ & -42 & $0.0035 \pm 0.0002^{\mathrm{c}}$ & -57 \\
\hline \multirow{4}{*}{$\begin{array}{l}\text { Oxygen: } \\
\text { Nitrogen } \\
(\mathrm{O}: \mathrm{N}) \\
\text { ratio }\end{array}$} & 7 & $32.66 \pm 0.641^{a}$ & $26.94 \pm 0.821^{b}$ & -17 & $22.52 \pm 0.746^{c}$ & -31 \\
\hline & 14 & $31.12 \pm 0.464^{\mathrm{a}}$ & $24.74 \pm 1.109^{b}$ & -20 & $18.53 \pm 1.068^{c}$ & -40 \\
\hline & 21 & $31.81 \pm 1.063^{\mathrm{a}}$ & $23.14 \pm 1.343^{\mathrm{b}}$ & -27 & $17.71 \pm 0.786^{c}$ & -44 \\
\hline & 28 & $31.53 \pm 0.468^{\mathrm{a}}$ & $18.82 \pm 1.571^{\mathrm{b}}$ & -40 & $12.80 \pm 1.038^{c}$ & -59 \\
\hline
\end{tabular}

Different superscript letters indicate significant $(P<0.05)$ differences between the groups 


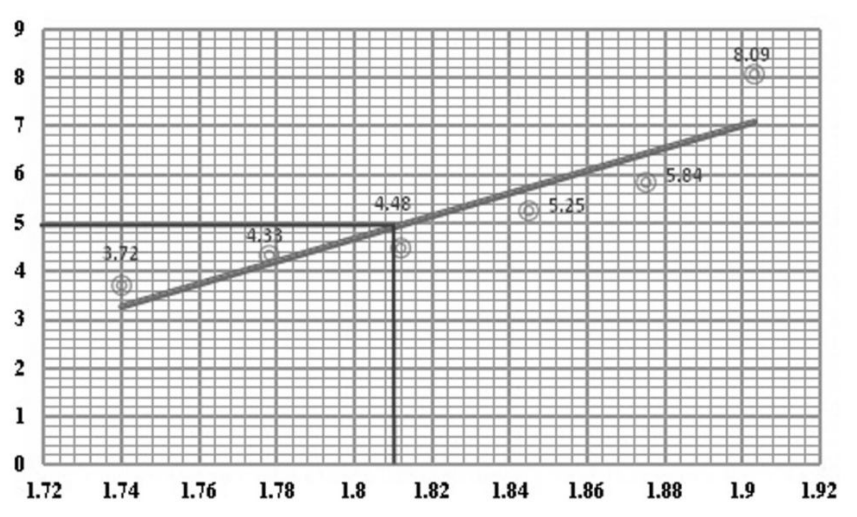

Fig. 1. Probit mortality of fry against $\log$ concentration of Tor khudree on exposure to fipronil

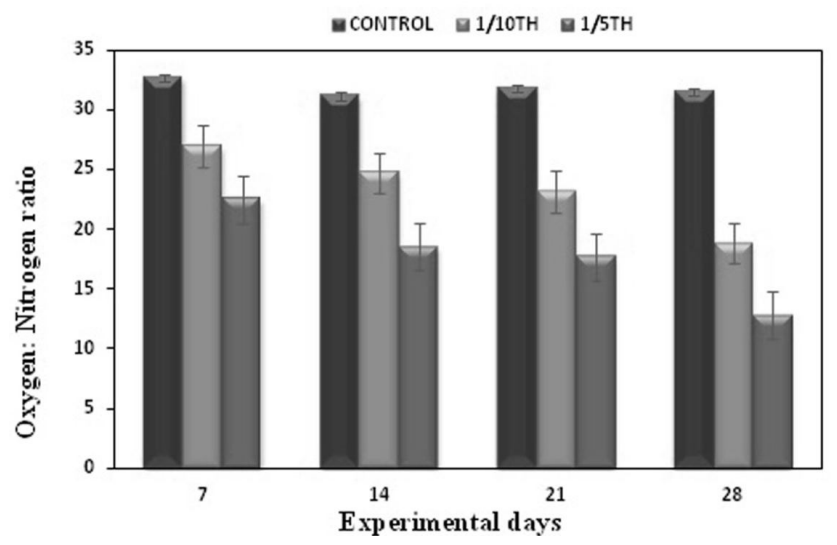

Fig. 3. Changes in the ammonia-N excretion rate ( $\mathrm{mg} \mathrm{g}^{-1} \mathrm{~h}^{-1}$ ) of Tor khudree fry when exposed to different sublethal concentrations of fipronil

\section{DISCUSSION}

Lethal toxicity: Earlier studies of the $\mathrm{LC}_{50}$ determination with different species of fish showed that fipronil had a high toxicity $(100-1000 \mu \mathrm{g} / \mathrm{L})$ in rainbow trout (Oncorhynchus mykiss, $246 \mu \mathrm{g}$ / L), Japanese carp (Cyprinus carpio, $340 \mu \mathrm{g} / \mathrm{L}$ ), sheephead minnow (Cyprinodon variegatus, 130 $\mu \mathrm{g} / \mathrm{L})$ and very high toxicity $(<100 \mu \mathrm{g} / \mathrm{L})$ in bluegill sunfish (Lepomismacrochirus, $83 \mu \mathrm{g} / \mathrm{L}$ ) and Nile tilapia (Oreochromis niloticus, $42 \mu \mathrm{g} / \mathrm{L}$ ) (Tingle et al., 2003). Comparison of the $\mathrm{LC}_{50}(64.6 \mu \mathrm{g} / \mathrm{L})$ value of fipronil in the present study with earlier authors measured for different species of fish showed some differences that may be due to

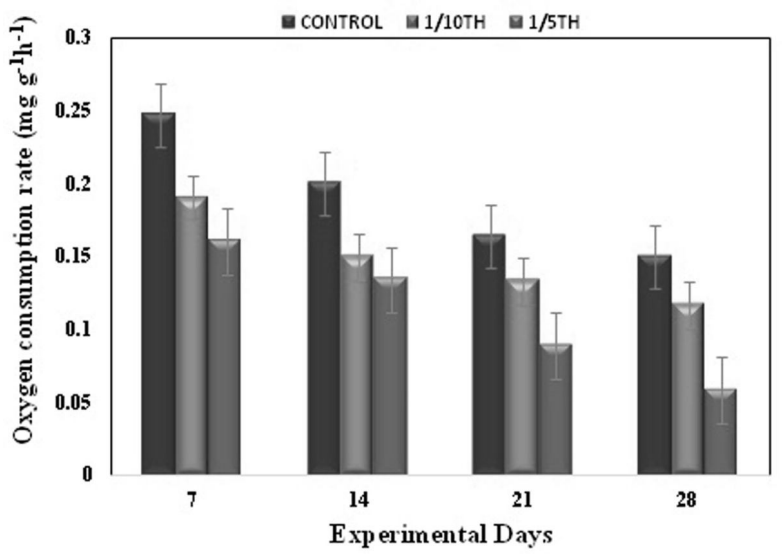

Fig. 2. Changes in the oxygen consumption rate $\left(\mathrm{mg} \mathrm{g}^{-1} \mathrm{~h}^{-1}\right)$ of Tor khudree fry when exposed to different sublethal concentrations of fipronil

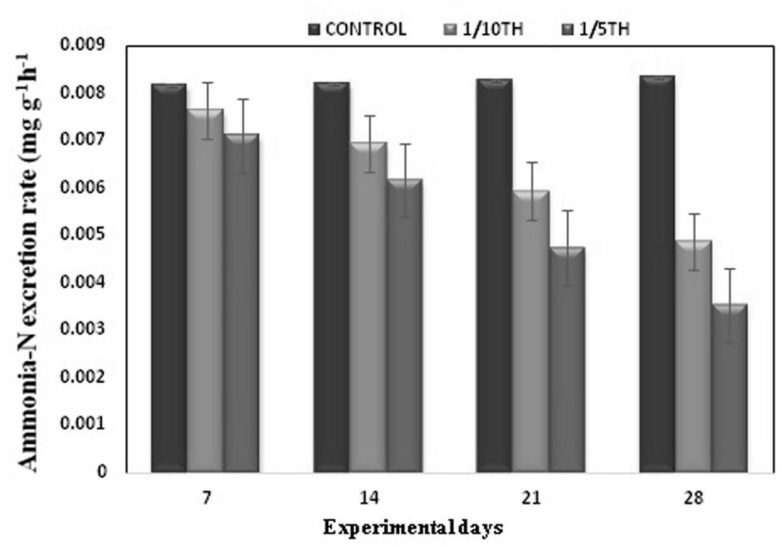

Fig. 4. Changes in the oxygen: nitrogen ratio of Tor khudree fry when exposed to different sublethal concentrations of fipronil

different species and weight of tested fish, the water quality characteristics and the purity of the fipronil.

Oxygen consumption: A decrease trend of oxygen consumption rate was observed under the both sublethal concentrations that may due to the toxicant induced stress and impairment of oxidative metabolism. On the off chance that gills or layer capacities are pulverized due to xenobiotic synthetic substances or the film capacities are upset by an adjustment in penetrability then oxygen take-up rate would quickly diminish (Hartl et al., 2001). 
In the present study decreasing $\mathrm{O}_{2}$ consumption of Mahseer fry were observed with increasing concentration of fipronil and exposure period. A similar trend was reported earlier under profenofos toxicity in Catla catla (Maharajan et al., 2013) and nuvan toxicity in Ctenopharyngodon idellaon (Tilak and Kumari, 2009). The fluctuated response in respiration may be attributed to reduction in gill permeability causing a drop in oxygen consumption for which the fish compensates by increasing the ventilation volume as observed by Kalavathy et al. (2001).

$\mathbf{N H}_{3}-\mathbf{N}$ excretion: Main excretion product of aquatic organisms is ammonia due to degradation of proteins. There are several examples of increased or decreased excretion of ammonia in fish subjected to stressful conditions, such as environmental contaminants, high concentrations of environmental ammonia, high $\mathrm{pH}$, air exposure, or crowding (Frick and Wright, 2002). The rate of ammonia release to the water is therefore closely related to the production of ammonia by the fish.

In the present study, fishes exposed to $6.46 \mu \mathrm{gL}^{-1}$ and $12.92 \mu \mathrm{gL}^{-1}$ of fipronil showed a significant drop in ammonia- $\mathrm{N}$ excretion rate as compared to control. A decrease in the ammonia-N excretion rate in both the sublethal concentrations may be due to toxicant induced stress, avoidance and biotransformation. Similar observation was reported by Barbieri (2009) during exposure of juveniles of Geophagus brasiliensis to $40 \mathrm{mg} / 12$,4D herbicide (2,4-Dichlorophenoxyacetic acid) causing $85 \%$ reduction in ammonium excretion compared to the controls. Fipronil caused a decrease in ammonia excretion rates proportionally at the highest concentration of pollutants. It is possible that the toxicant induces changes in metabolism, which increases catabolism. However, at higher concentrations,

\section{REFERENCES}

APHA, 2012. Standard methods for the examination of water and waste water, $22^{\text {nd }}$ edn., American Public Health Association, Washington, DC, pp560

Barbieri E, 2009. Effect of 2, 4-D herbicide (2, 4- the decrease observed could be a reflex of a loss in the ability to excrete, probably due to an effect of the xenobiotic over cells involved in excretory activities (de Medeiros et al., 2020).

O:N Ratio: In the present study, fish exposed to two sublethal concentrations of fipronil, showed a decrease in O: $\mathrm{N}$ ratio when compared to the control. It has been observed that the effects of fipronil on Tor khudree suggested that pesticides might interfere differently with different physiological processes, such as calcium metabolism, ionic regulation, respiration, excretion or enzymatic processes. The results obtained in the present study are similar to the findings of many scientists. Dhamagaye et al. (2015) documented decreased O:N ratio of Pangasinodon hypophthalmus as concentration of cypermethrin increased indicating an alteration in energy utilization. However, Montagna and Collins (2008) reported a decreased O:N ratio with higher concentration of chlorpyrifos and an increment in the O:N ratio in the lower concentration of endosulfan solutions in freshwater crab Trichodactylus borellianus. Records of high O:N ratio suggested that, it was primarily due to metabolism of lipid or carbohydrate metabolism, and a lower $\mathrm{O}: \mathrm{N}$ ratio indicated a protein metabolism. The values of O:N ratio were less than 10 in all stressed conditions. O:N values recorded under conditions for both species suggested the predominance of protein catabolism. The use of protein as fuel is generally indicative of stressful conditions in exposed fishes (SchmidtNielsen, 1997).

According to the present study, low oxygen:nitrogen ratio in sublethal group is due to protein catabolism. The oxygen:nitrogen showed a decrease in sublethal concentrations of fipronil, indicating a shift towards protein primary metabolism corresponding to an alteration in energy utilization.

dichlorophenoxyacetic acid) on oxygen consumption and ammonium excretion of juveniles of Geophagus brasiliensis (Quoy and Gaimard, 1824) (Osteichthyes, Cichlidae). Ecotoxicology,18(1): 55-60 
Brahmane MP, Krishnani KK, Sarkar B, Sajjanar B, Kumar S et al., 2014. Growth, thermal tolerance and oxygen consumption in rohu, Labeo rohita early fry acclimated to four temperatures. Afr J Agr Res, 9(9): 854-858

Chagnon M, Kreutzweiser D, Mitchell EAD, Morrissey CA and Noome DA, 2015. Risks of large-scale use of systemic insecticides to ecosystem functioning and services. Environ Sci Pollut Res, 22(1): 119-134

de Medeiros AM, Coa F, Alves OL, Martinez DS and Barbieri E,2020. Metabolic effects in the freshwater fish Geophagus iporangensis in response to single and combined exposure to graphene oxide and trace elements. Chemosphere, 243: 125316

Devi R and Boguskaya N, 2007. Tor khudree. In: IUCN 2010, IUCN Red List of Threatened Species, Version 2010.2 http://www.iucnredlist.org/. Accessed on 23 August2010

Dhamagaye HB, Gowda GC, Shruthisree C, Nayak H and Meshram SJ, 2015. Oxygen consumption and ammonia excretion of iridescent shark, Pangas inodonhypophthalmus exposed to cypermethrin. J Exp Zool India, 18: 381-385

EPAR, 1998. Yearbook of environmental information of the Republic of China. EPA, R.O.C., Taipei, Taiwan, pp141-142

Finney DJ, 1971. Probit analysis $3^{\text {rd }}$ edn., Cambridge University press, London, pp508-510

Frick NT and Wright PA, 2002. Nitrogen metabolism and excretion in the mangrove killifish, Rivulus marmoratus $\mathrm{I}$. The influence of environmental salinity and external ammonia. J Exp Biol, 205(1): 79-89

Golterman HL, Clymo RS and Ohnstad, M 1969. Method for chemical analysis of fresh water. Oxford Blackwell Scintific Publication, IBP Handbook, 8, pp180

Hartl MGJ, Hutchinson S and Hawkins L, 2001. Organotin and osmoregulation: quantifying the effects of environmental concentrations of sediment asociated TBT and TPhT on the fresh water adapted European flounder, Platichthys flesus. J Exp Mar Biol Ecol, 256(2): 267-278
Job SV, 1957. The routine-active oxygen consumption of the milk fish. Proc Indian Acad Sci, 45(6): 302-313

Kalavathy K, Sivakumar AA and Chandran R, 2001. Toxic effects of the pesticide dimethoate on the fish Sarotherodon mossambicus. J Ecol Res Bio, 2: $27-32$

Maharajan A, Usha R, Ruckmani PS, Vijaykumar BS, Ganapiriya V et al., 2013. Sub lethal effect of profenofos on oxygen consumption and gill histopathology of the Indian major carp, C. catla. Int J Pure Appl Zool, 1: 196-204

Montagna MC and Collins PA, 2008. Oxygen consumption and ammonia excretion of the freshwater crab Trichodactylus borellianus exposed to chlorpyrifos and endosulfan insecticides. Pestic Biochem Physiol, 92(3): 150-155

Pinder AC and Raghavan R, 2013. Conserving the endangered Mahseers (Tor Spp.) of India: The positive role of recreational fisheries. Current Sci, 104(11), Accessed May 21, 2020, www.jstor.org/stable/24092466

Schmidt-Nielsen K, 1997. Animal physiology: adaptation and environment. Cambridge University Press, pp607

Tilak KS and Kumari R, 2009. Acute toxicity of Nuvan ${ }^{\circledR}$, an organophosphate to freshwater fish Ctenopharyngodon idella and its effect on oxygen consumption. J Environ Biol, 30(6): 1031-1033

Tingle CC, Rother JA, Dewhurst CF, Lauer S and King WJ, 2003. Fipronil: environmental fate, ecotoxicology, and human health concerns. Reviews Environ ContamToxicol, 176: 1-66

Widdows J, 1985. Physiological procedures. The effects of stress and pollution on marine animals. Bayne B L, Praeger, New York, pp61-168

Zhen Y, Aili J and Changhai W, 2010. Oxygen consumption, ammonia excretion, and filtration rate of the marine bivalve Mytilusedulis exposed to methamidophos and omethoate. Mar Freshw Behav Physiol, 43: 243-255 